\title{
Hvilke moralske utfordringer opplever norske politistudenter i praksisåret?
}

\author{
Jens Erik Paulsen, Lisa Maria Enoksen
}

Politihøgskolen, avd Oslo Filosofisk praktiker, jens.erik.paulsen@phs.no

Politihøgskolen - studieavdelingen, Lisa.Maria.Enoksen@phs.no

DOI: http://dx.doi.org/10.5324/eip.v11i2.1986

(cc) BY

This is an open access article distributed under the terms of the Creative Commons Attribution 4.0 International License, which permits unrestricted use, distribution, and reproduction in any medium, provided the original author and source are credited.

I denne studien undersøkes hvilke moralske utfordringer norske politistudenter oftest møter $i$ «praksisåret». Utfordringene identifiseres gjennom en analyse av 208 hjemmeeksamener i yrkesetikk fra avgangsstudentene ved Politihøgskolen i Oslo, hvor utfordringene beskrives gjennom kombinasjoner av hvilke verdier som står sentralt, hvilke personer som er involvert og hvilke typer oppdragene oppstår i. Funnene eksemplifiseres og settes $i$ forhold til sentrale politivitenskapelige diskusjoner. Til slutt diskuteres hvordan studentene best kan forberedes på disse utfordringene.

Nøkkelord: etikk, yrkesetikk, anvendt etikk, politi, utdanning

English summary: What moral challenges are Norwegian police students encountering during their practice period?

This article examines what moral challenges Norwegian police students encounter during their practice period. The challenges are identified through an analysis of the experiences described in the professional ethics home exams of 208 graduates at the Norwegian Police University College in Oslo. From our analysis, paradigmatic challenges are constructed based on the combinations of values, persons and mission types typically highlighted in the exams. These challenges are then discussed in light of central topics in police science. Finally, we discuss briefly how police students can be best prepared for meeting these moral challenges.

Keywords: ethics, professional ethics, applied ethics, policing, education

\section{Innledning}

Norsk politiutdanning består av et treårig bachelorløp hvor studentene er utplassert ved en politistasjon eller et lensmannskontor i andreåret. Hovedspørsmålet i denne artikkelen er «Hvilke moralske utfordringer møter norske politistudenter i dette praksisåret?» $\AA$ tematisere studentenes friske blikk på politietaten synes viktig, ettersom det er et uttalt behov for kulturendring (se f.eks. NOU 2012:14 eller NOU 2013:9). Et svar på dette spørsmålet vil også kunne bidra til å forberede fremtidige politistudenter på å møte praksisfeltet, og slik minske det "praksissjokket» (Smeby 
2007) mange studenter synes å møte - også i andre såkalte menneskebehandlende yrkesutdanninger. I nærværende sammenheng kan slike praksissjokk skyldes at tjenesten er annerledes enn man har forestilt seg, at det er erfaringskunnskap og ikke skoleflinkhet som gir status (Gundhus 2009: 105, Sjøtrø \& Olsen 2013: 6), og tidvis at erfarne yrkesutøvere aktivt tar avstand fra den akademiske skolelærdom studenten har tilegnet seg: «Du skal vite at alt du har lært på skolen, er bare å glemme. Dette er den virkelige verden» (Johannessen 2013: 154). Slike utsagn utfordrer fort studentenes faglige integritet i den grad de har tatt skolelærdommen alvorlig. Dette oppleves ikke nødvendigvis som noe «sjokk», men det genererer lett en form for «moralsk stress» (Epstein \& Delgado 2010) og et ønske om mestring for å kompensere for dette. Mot slutten av praksisåret skal jo dessuten politistudentens egnethet for yrket vurderes av praksisveilederne. Hvilke situasjoner er det så som genererer stress og utfordrer studentene i moralsk forstand? Hvordan takler studentene disse utfordringene, og kan studentene forberedes på å møte disse situasjonene på skolebenken?

\section{Metodisk tilnærming}

For å finne svar på hovedspørsmålet, studerte vi avgangsstudentenes hjemmeeksamener i yrkesetikk fra våren 2013, hvor de skulle besvare følgende oppgave:

«Presenter en situasjon fra praksisåret som utfordret dine holdninger (husk anonymisering!), og forklar kort hvorfor du oppfattet situasjonen som utfordrende. Drøft deretter måten situasjonen ble håndtert på i lys av yrkesetiske verdier og normer. På bakgrunn av drøftingen, avslutt oppgaven med å gi et råd til en [førsteårs]-student som spør deg hvordan hun/han best kan forberede seg på en lignende situasjon.»

Mange anekdoter fra besvarelsene kunne vært gjenfortalt, men i denne artikkelen er det fellestrekkene ved de 208 undersøkte bidragene som løftes frem. Fokus ligger altså på de vanligste utfordringene snarere enn de mest spektakulœere. Vi forventet at overvekten av utfordringene ville dreie seg om fysisk maktbruk, ettersom politiet er statens redskap for maktutøvelse i fredstid. Undersøkelsen viste imidlertid at politistudentene i større grad pekte på skjønnsutøvelse, tingliggjøring, og ivaretakelse av sårbare individer - temaer som er relevante problemstillinger i de fleste menneskebehandlende yrker og yrkesutdanninger.

For å minimere slagsiden i undersøkelsen, tok vi utgangspunkt i frekvensene av utfordringer i studentbesvarelsene, snarere enn vår forforståelse eller emner som ofte tematiseres i politivitenskapen. Materialet ble kodet i henhold til tre sider ved de utfordringene som studentene presenterte, nemlig (1) hvilke verdier de mente sto på spill i situasjonen; (2) hvem de opplevde å stå i en utfordrende 'interessekonflikt' med; samt (3) hvilke oppdragstyper utfordringene oppsto i. De vanligste kombinasjonene av disse tre perspektivene representerer da de typiske scenarioene.

For oppdragstypenes del ble kodingen basert på politiets oppgaver som definert $\mathrm{i}$ Politiloven $\$ 2$. De øvrige to perspektivene ble basert på de betegnelsene på verdier og personer som fantes i fortellingene. Ettersom studentenes begrepsbruk varierte i betydelig grad, og vi ikke ønsket å låse oss til kategorier som etter hvert ikke var treffende, benyttet vi en "grounded theory»-metodologi (Glaser \& Strauss 1999). ${ }^{1}$ Det vil si at vi reviderte kategoriene og tilpasset dem til kildematerialet underveis. 
Kodingsskjemaet måtte dermed revideres flere ganger underveis, og kildematerialet ble gjennomgått gjentatte ganger inntil kategoriene etter vårt skjønn representerte kildematerialet på en tilfredsstillende måte. Kodene ble så lagt inn i et Excel-ark og ulike sammenhenger mellom de tre perspektivene sporet. På bakgrunn av disse analysene skisseres senere i artikkelen fem scenarioer som illustrerer «vanlige» utfordringer i materialet. Disse reflekteres inn i en nordisk så vel som angloamerikansk teoretisk sammenheng i siste del av artikkelen. Refleksjonsdelen er relativt kort, ettersom generering av teori og konseptuell generalisering var viktigst (Tjora 2012: 209) i dette stadiet av prosjektet. I en senere fase av prosjektet vil diskusjon av validitet og sammenheng med andre studier få en større plass, samt hvordan koherensen mellom teoretisk og praktisk del av studiet kan bedres - det Smeby og Heggen (2014) refererer til som "programme coherence» i utdanningssammenheng.

Datamaterialet har mange mulige feilkilder. Ved en eksamen ønsker studentene å demonstrere ferdigheter i pensum. Denne tendensen er tydelig i drøftingsdelen av studentbesvarelsene. I kodingsprosessen var imidlertid besvarelsenes første del viktigst, der studentene kort presenterte en hendelse og forklarte hvorfor den opplevdes som utfordrende. Selvsagt er det feilkilder også her: noen av redegjørelsene kan være rene fiksjoner eller gjengivelser av andres opplevelser. I tillegg kan tenkes at studentene har misforstått situasjonen han/hun beskriver. $\AA$ vurdere ektheten av et anonymt og anonymisert dokumentmateriale er vanskelig. Derfor problematiseres ikke studentenes fortellinger i denne studien, men snarere var målet å bevare studentenes perspektiv. Kodingen representerer slik en «intensjonal lesning» (Abbott 2002) av materialet. ${ }^{2}$ Ettersom studien slik begrenser seg til en intensjonal lesning, og eksamensoppgaven var formulert slik at den inviterte til å drøfte utfordringer som tok utgangspunkt i situasjon mer enn relasjon, er antakelig utfordringer som går på veileder/student-forholdet underrepresentert. Dette er en begrensning ved studien som bør tas hensyn til i en videre studie.

Studien (prosjektnr. 34687) ble vurdert av Norges Samfunnsvitenskapelige Datatjeneste og uttalelse derfra gitt 9. juli 2013. Prosjektet ble vurdert som akseptabelt av Politihøgskolen, og innsyn til materialet ble gitt av ledelsen i august 2013, med henvisning til Offentlighetsloven $₫ 3$ og Åndsverkloven $\$ \$ 27$ og 28. Studentene ble orientert om studien per epost den 23. august 2013.

\section{Resultater}

I kodingen av de 208 eksamensbesvarelsene studerte vi (1) hvilke verdier studentene mente stod på spill, (2) hvilke parter som var involvert og (3) hvilke oppdragstyper utfordringen oppstod i. For tydelighetens skyld refererer vi til Oppdragstypene og de ulike Aktørene med stor forbokstav, og verdiene i kursiv.

\section{(1) Verdilandskapet i materialet}

Moralske utfordringer oppstår når viktige menneskelige eller faglige hensyn ikke ivaretas, når balansen mellom ulike hensyn oppleves som skjev, eller når normative hensyn synes å trekke $i$ ulike retninger. Normative hensyn utgjøres i forskningsmaterialet dels av nedskrevne lover, dels av etiske prinsipper, men oftest av følte moralske hensyn ${ }^{3}$. For eksempel kan studentene mene at loven tilsier strikt likebehandling i en situasjon, mens yrkespraksis på tjenestestedet synes å gi stort rom for å avvike fra prinsippet om likebehandling. I noen tilfeller mener studentene 
at utfordringene kunne vært unngått med små justeringer - for eksempel ved å ta seg litt bedre tid - mens oppdragsløsningene andre ganger fremstår som tvilsomme eller direkte kritikkverdige. Studentene har ofte sterke meninger i verdispørsmål (Winnæss 2014: 105-6), men selvsagt kan de ikke bare følge sitt private moralske kompass - de befinner seg jo nederst på rangstigen i en hierarkisk organisasjon. De ønsker å fremstå som dugelige og lojale og tar medansvar for handlinger de selv ikke synes er optimale. Å innta politirollen er slik både spennende og meningsfullt, men når det går på integriteten løs, sier de bare unntaksvis ifra direkte til overordnet om dette. I høyden benytter de det Øyvind Kvalnes (2008: 160) kaller en «hint og håp»strategi. Både i eksamensbesvarelsene og i klasserommene snakker politistudentene om praksisåret som en «lang jobbsøknad». I seks slike tilfeller skriver studentene at de manglet dyden mot til å si ifra.

Ettersom verdibetegnelsene er lite standardiserte i kildematerialet, er kategoriene snarere samlebegreper for «familielike» begreper (Wittgenstein 1997: § 66). Disse sammenslåingene redegjøres for under hver enkelt verdi. Seks slike normative eller verdiladde samlebegreper skiller seg ut i materialet: forutinntatthet scorer høyest og står sentralt i $38 \%$ av besvarelsene. Med samme hyppighet opptrer det mer prinsipielle likhet (35\%). Forekomsten av medfølelse og lovverk ligger begge på 25 $\%$, foran verdighet (20\%) og tvangsmakt (18\%). I det følgende redegjøres det for disse seks, samt de kontekstene de oftest opptrer i.

Forutinntatthet er et samlebegrep som fanger betegnelser i materialet som: «fordom», «rasisme», «dårlig holdning», «generalisering», «kynisme», «inngrodd oppfatning» eller «mangel på åpenhet». Begrepet representerer en holdning til mennesker, grupper av mennesker eller individer. Studentene er ofte ambivalente til den forutinntattheten de mener å se både hos andre tjenestepersoner og i seg selv. Med all erfaring genereres selvfølgelig forståelse og forventninger - dette er nødvendig for å kunne orientere seg i verden. I nordisk politivitenskap kalles denne spesialiserte forståelsen gjerne for 'politiblikket' (Finstad 2000) ${ }^{4}$ - det erfarne blikket som gjør at man har situasjonsforståelse og begrep om farer, muligheter og sannsynligheter. Dette blikket skal «oppdage, avsløre, være til hjelp for publikum, gripe inn mot straffbare forhold. Politiblikket er et inngripende, kontrollerende blikk og et beskyttende, hjelpsomt blikk» (Finstad 2000: 60). Dette utgjør en viktig del av ekspertisen, fordi en politibetjents evne til å utøve yrket effektivt er basert på evnen til å gjenkjenne tegn på at kriminalitet har foregått eller er i emning. Studentene forsøker i praksisåret å tilegne seg slik ekspertise fra erfarne tjenestepersoner, men slik erfaringslæring går for langt når mennesker på gata «fanges» av stereotypier, når åpenhet blir umulig. I materialet slår nemlig forutinntatthet sjelden ut i favør av klienten. Nettopp derfor fremheves antakelig også verdier som transparens, åpenhet og ivaretakelse av egen og andres integritet som viktige i etiske retningslinjer som for eksempel i Politiinstruksen (1994) eller i det skotske politiets etiske prinsipper (se MacVean \& Neyroud 2012: 28-29). Dette er verdier som bør prege etaten, men det er altså forutinntattheten - motsetningen som fremholdes som den sentrale betegnelsen i eksamensbesvarelsene. Er forutinntatthet en verdi? Den er i hvert fall basert på erfaringskunnskap og slik normativ (prescriptive) og retningsgivende for handlinger (action guiding) - hvilket er rollen verdier ofte har (se for eksempel Richard M. Hare (1952)). 
I materialet er det særlig tre grupper personer som nevnes i forbindelse med forutinntatthet: personer som allerede figurerer i politiets registre (Kjenninger), selgere/brukere av illegale rusmidler (Rusbelastet), eller folk med opphav fra andre land (Utenlandsk). Studentene tviler gjerne på om forutinntatthet var på sin plass («han kan jo være uskyldig...», «hun er jo også et vanlig menneske...»), men ofte rasjonaliseres tvilen like snart bort: «Jeg reagerte på tjenestehandlingen, men min veileder har selvfølgelig mer erfaring enn meg, og er kjent som en god politibetjent...». Studentens egne verdier står da i motsetning til makkers eksempelmakt, og det oppleves vanskelig å fronte egne - og etatens offisielle verdier som respekt og omtanke for personers integritet. I materialet synes det klart at studentene både beundrer forutinntatthet som uttrykk for ekspertise, samtidig som de frastøtes av forutinntatthet som uttrykk for mangel på åpenhet.

Når forutinntatthet diskuteres i materialet er det aller oftest i forhold til personer som beskrives som 'utenlandske'. En student beskriver hvordan patruljen observerer en ung mann med afrikansk utseende til fots i et rolig boligstrøk midt på natten. Studenten får beskjed om å kontrollere mannen og passe på at han ikke «kaster noe fra seg». Mannen finner ikke legitimasjonen straks og stotrer at han er seint ute fordi han har sett film med noen venner. Makker (en politibetjent) kommer brått ut av bilen og overtar - spør mannen hvor han kommer fra, hvor han skal, og spør igjen etter ID. Makker spør videre om mannen har brukt narkotiske stoffer, og lyser ham i øynene og sier at pupillene er litt forstørret. På sambandet opplyses det at vedkommende ikke finnes i politiets registre. Makker beslutter likevel at mannen må ransakes. Ransakingen foregår rolig, men blir resultatløs. Den unge mannen får en beklagelse, men også beskjed om at kontrollen «dessverre var nødvendig». Mannen later til å godta dette og ønskes en god natt. Studenten synes at grunnlaget for kontrollen var noe spinkelt, avviser at makker er rasist, men snarere svært opptatt av narkotika, som jo er et stort samfunnsonde. Hendelsen forklares med et sammentreff av tid, sted og person. Makker vet hva som står på spill.

Samlebegrepet likhet står sentralt i 72 av besvarelsene. Oftest refererer studentene til likhetsprinsippet - det vil si til et aristotelisk likebehandlingsprinsipp (Kvalnes 2008: 56), men innbefattet i begrepet er også nøytralitet, upartiskhet (Politiloven $\S$ 6) og referanser til 'rettferdighetssans'. Uttrykk som 'skjønn' og 'konduite' trekkes ofte inn i denne sammenhengen. Samlebegrepet opptrer oftest i forbindelse med oppdrag som har med trafikk å gjøre, og i trafikksammenheng karakteriseres sjelden personene nærmere i vårt materiale. En situasjon som beskriver en utfordring i forhold til likhet er en trafikkontroll der målet til patruljen er å informere om et nytt, tidsavgrenset innkjøringsforbud. Oppdraget går som planlagt inntil en sjåfør stanses og reagerer kraftig på at han må kjøre en omvei. Han kommer med ufine bemerkninger, og til slutt har han «snakket på seg» et forenklet forelegg. Neste bil stoppes for kontroll før den kranglete sjåføren har forlatt stedet og denne sjåføren får også et forenklet forelegg for å ha kjørt mot det nye forbudsskiltet - antakelig mest for ikke å skape ytterligere problemer med den kranglete sjåføren. Dermed er den informerende linjen forlatt. Studentene spør seg da gjerne om hva det betyr å behandle like tilfeller likt og hvor mye som skal til for å «snakke på seg» et forelegg. I praksis er det ofte vanskelig å holde en rettferdig linje.

Ser vi bort fra de aktørnøytrale trafikkoppdragene karakteriseres personene som figurerer i likhets-utfordringene typisk som Rusbelastede eller Utenlandske, og sistnevnte kategori er her overrepresentert. 
Samlebegrepet medfølelse rommer familielike begreper som hensynsfullhet, empati, sympati og omsorg - begreper som lett kan skilles fra hverandre, men som ofte glir over i hverandre både i dagligtale og i studentenes eksamensbesvarelser. Når medfølelse nevnes står et nærhetshensyn på spill: en person befinner seg i en situasjon som er hjerteskjærende, eller det er noe ved personen som appellerer til studentens følelser. Studentene ønsker uansett å vise medfølelse, eller ta seg bedre tid til vedkommende, men dette virker å være uforenlig med praksis eller ordre. $\AA$ agere følelsesmessig nøytralt (Christoffersen 2011: 27, Politiloven $\S 6$, Politiinstruksen $₫ 3-1$ ) - eller i det minste med selvkontroll (Freidson 2007: 19) - er et ideal i de fleste profesjoner, og dette kan kjennes uvant. Det er dessuten mange hensyn politiet ikke kan forventes å $t a$ - selv om politibetjentene ser hensynet. Derfor blir det for enkelt å si at mangel på medfølelse skyldes veileder/makkers forutinntatthet. Forutinntatthet og medfølelse kan faktisk trekke i samme retning, for eksempel når man forsøker å hjelpe mennesker som ikke ønsker hjelp ut ifra det man mener åpenbart må være deres beste interesse. Medfølelse fremheves i 55 av oppgavene, og personene som studentene har medfølelse med er oftest karakterisert som rusbelastet. Mange av disse blir påtruffet under såkalte «husbråk»-oppdrag, hvilket her betyr ordensforstyrrelser i private hjem. Typisk gjør klientens livssituasjon et sterkt inntrykk på studenten, særlig hvis vedkommende ikke synes å kunne bryte ut av en destruktiv tilværelse. Hjelpemotivet - som er et viktig moment i utdanningsvalget for mange av studentene (Winnæss 2014: 102-103) - kommer her til uttrykk, men da i form av en avmaktsfølelse.

Normen lovverk refererer til alle skrevne rettskilder. I materialet refererer begrepet oftest til Politiloven eller -instruksen, for eksempel gjennom utsagn som «Jeg mener oppdragsløsningen ikke samsvarte med Politiloven $₫ 6$ ». At lovverk skårer såpass høyt i en etikkeksamen er for så vidt naturlig. Ifølge Rolf Granér er studenter/nyutdannede ofte opptatte av å gjøre ting riktig «etter boka», og «boka» er i stor grad lover og instrukser (Granér 2004: 75). Politiinstruksen beskriver dels også måten tjenestehandlinger skal utføres på. I materialet står lovverk sentralt i 52 tilfeller, og personene som omtales i lovverk-eksemplene er ofte beskrevet som rusbelastede eller kjenninger (og i flere tilfeller som begge deler). I lovverkutfordringene er studenten ofte usikker på om tjenestehandlingen er «innafor». Dette kan for eksempel dreie seg om utrykning til en fest hvor melder mistenker at en angivelig ruset person skal til å kjøre bil. Vedkommende har flere småsaker på rullebladet fra tidligere. Politiet kommer til adressen før vedkommende har kjørt avgårde, og kan avverge at sjåføren overhodet setter seg bak rattet, men i stedet stiller patruljen seg opp for å vente og heller stanse ham etter at han har begynt kjøreturen. Studenten er absolutt innstilt på å få tatt vedkommende, men i bakhodet lurer tanken Hva om en ulykke skjer før han stoppes, eller om dette utvikler seg til en biljakt? Studenten er også usikker på om lovverket - eksempelvis Politiloven $₫ 2$ som også beskriver politiets oppgaver som å verne og forebygge - tillater at man nærmest setter opp en felle på denne måten. I utgangspunktet skal ikke politiet operere slik, men andre hensyn kan spille inn.

Verdien verdighet omfatter dels «respekt for menneskeverd», men også andres 'integritet'. Aktørenes verdighet står på spill, uten at dette nødvendigvis sies å ha direkte med lovverk, medfølelse eller likhet å gjøre. Oftest nevnes verdighet i møtet med hjelpetrengende personer, beskrevet som 'psykisk syke' eller 'unge'. Det kan være vanskelig å ivareta slike personers verdighet i offentligheten, spesielt når de 
utagerer, eller når sinnsreserven deres er lav slik at de lett kan miste selvkontrollen. Enten tenker studentene at man kunne ha gjort mer for å ivareta personens verdighet, eller så ser de at dette er vanskelig å få til, på grunn av tidsmangel eller andre hensyn. I siste tilfelle utgjør dette et moralsk dilemma. Det blir galt enten man handler resolutt eller forsøker å kommunisere.

Den siste verdien som studeres her er korrekt (dvs. minimal) anvendelse av tvangsmakt - her for enkelhets skyld benevnt «tvangsmakt». Ikke-skadeprinsippet (Beauchamp \& Childress 2009) utgjør en parallell i helsevesenet. Politiets retningslinjer oppfordrer til tilbakeholdenhet av maktbruk (Politiloven $₫ 6$, Politiinstruksen $₫ 3-1$ ), men politiets oppgave er likevel å håndheve lov og orden på vegne av staten - ved hjelp av fysisk tvangsmakt i den grad nødvendig. I materialet er bruken av fysisk tvangsmakt som regel godt hjemlet, men oppfattes likevel som utfordrende. Typisk skjer dette når klienten det utøves makt overfor beskrives som Hjelpetrengende og Psykisk syk eller Ung. Studenten fremholder som regel da at patruljen burde ha kommunisert ytterligere med vedkommende, eller at man hadde unnlatt å benytte maktmidler som håndjern. En situasjon som illustrerer denne utfordringen: Patruljen skal bistå med å få en ung jente tilbake til institusjonen der hun bor. Hun motsetter seg kraftig, og patruljen må anvende mer makt enn studenten hadde forestilt seg kunne være nødvendig. Maktbruken foregår dessuten i påsyn av foreldre og kanskje naboer.

Som nevnt er det ofte konflikter mellom verdier som gjør at moralske utfordringer oppstår. Forutinntatthet står sentralt i de fleste av disse. To kombinasjoner skiller seg ut. Oftest (25 ganger) forekommer situasjoner der forutinntatthet diskuteres opp mot likhet, og i disse tilfellene står personer karakterisert som Utenlandsk sentralt i situasjonen. Det er ikke noen spesiell oppdragstype som skiller seg ut i disse tilfellene. En annen fremtredende sammenstilling er forutinntatthet-medfølelse (22 ganger). I denne kombinasjonen opptrer person kategorisert som Rusbelastet oftest - og dette er gjerne i sammenheng med de ellers ikke særlig fremtredende «Husbråk»-oppdragene.

(2) Personbeskrivelser

Å håndtere interessekonflikter står sentralt i profesjonsutøvelse (Nanda 2003) og spesielt i politiyrket. Til forskjell fra i mange yrker, er disse konfliktene ikke uønskede; forbrytelser og gjerningspersoner gjør jobben spennende, kanskje særlig i studentpraksisen («rävfasen») og den tidlige, «hungriga» delen av karrieren (Granér 2004: 76). Kanskje nettopp derfor synes selve forbrytelsene eller ordensforstyrrelsene bare unntaksvis å utfordre studentene moralsk i besvarelsene. Utfordrende blir det snarere når politiet $i k k e$ griper inn, eller oftest: når studenten er usikker på om måten politiet griper inn på er riktig.

Konfliktene som beskrives i eksamensoppgavene har i $95 \%$ av tilfellene utspring i Politiets tjenestehandlinger. Som vi har sett stiller studentene seg spørsmål som: Hadde vi egentlig hjemmel (lovverk)? Var det moralsk forsvarlig (verdighet)? Brukte vi for mye makt (tvangsmakt) overfor personen? Var vi hensynsfulle nok overfor personen (medfølelse)? Det betyr ikke at politiet opptrer klanderverdig, men at studentene ikke nødvendigvis er komfortable med politiets atferd overfor den annen part. 'Politiet' refererer her i halvparten av tilfellene til Patruljen studentene er en del av, dernest mer spesifikt til Makker/Kollega (26\%), og sjeldnere mener studentene at deres egne handlinger og holdninger alene er kilden til den moralske utfordringen (16\%). I det følgende legges liten vekt på disse distinksjonene, 
ettersom både anonymisering og lojalitetshensyn gjør det vanskelig å vurdere påliteligheten av denne informasjonen. Ofte ser vi utsagn som «Jeg kjørte med en politibetjent som ikke var min veileder...», eller: "makker var fra et annet tjenestested...». Så langt 'Politiets' rolle i konflikten.

På den «andre siden» av interessekonflikten forekommer, ikke uventet, rollekategorien 'Gjerningsperson' oftest (44\%). Av øvrige rollebetegnelser som skårer relativt høyt er Politi-Hjelpetrengende (14 \%), Politi-Publikum (13\%) og Politi-Fornærmet (9\%). ${ }^{5}$

Ser vi bort fra rollen til klienten og kun fokuserer på personbeskrivelsene politistudentene benytter, figurerer personer karakterisert som Rusbelastet hyppigst i besvarelsene (27 \%). Dernest følger personer beskrevet som Utenlandsk, Kjenning, Psykisk syk og Ung omtrent med samme frekvens (13-15\%). Rusbelastet skiller seg altså klart ut. Med Rusbelastet menes her personer som antas å ha en avhengighet til narkotika eller alkohol. I konfliktene mellom Politi og Rusbelastet preges verdilandskapet av en jevn fordeling av lovverk, likhet, medfølelse og forutinntatthet. Når verdienes generelle frekvens kompenseres for, fremstår lovverk som overrepresentert i sammenheng med Rusbelastet. I de besvarelsene som omhandler Rusbelastet person er det typisk at patruljen kontrollerer vedkommende (inngående spørsmål, ransaking), noe studenten ikke alltid helt vet om er korrekt i forhold til ordensjussen. Den ellers sjeldne verdien oerlighet $(11 \%)$ - at patruljen ikke er sannferdige - gjør seg utelukkende gjeldende i politiets møte med Rusbelastet i dette materialet.

I 31 tilfeller karakteriseres en sentral aktør som 'Utenlandsk'. I de aller fleste tilfellene refereres da til menn av afrikansk eller øst-europeisk opphav, i sistnevnte tilfelle som regel romfolk eller personer som mistenkes for å være mobile vinningskriminelle. Dette er personer som ut ifra utseende, bilnumre eller adferd (tigging) lett lar seg identifisere, også av politistudentene. I saker som omhandler møter med Utenlandsk person aktualiseres forutinntatthet i mer enn to-tredjedeler av eksemplene. To andre verdier nevnes også hyppig her, nemlig likhet (58 \%) og lovverk (32\%). Studentene spør seg om tjenestehandlingene overfor Utenlandsk person er basert på forutinntatthet, om handlingene er i tråd med likhets-prinsippet og om de er «innafor» i forhold til lovverket. Men som vi så i verdilandskapet er studentene ambivalente overfor forutinntatthet som ekspertise. De befinner seg jo i en læresituasjon og skal lære skjønnsutøvelse og håndhevelse av lovverket i praksis, og ser at denne erfaringskunnskapen kan være nyttig. Men ut ifra opptaksprøvene og undervisningen i forkant av praksisåret, er studentene bevisste på egne fordommer og på å ivareta menneskeverd. Forskjellsbehandling tilsynelatende kun ut ifra utseende, bilnumre eller avvikende atferd, kan da fort oppleves som utfordrende.

Karakteristikken 'Kjenning' opptrer like hyppig som Utenlandsk i materialet. En Kjenning har vært i kontakt med politiet tidligere som gjerningsperson eller mistenkt, og kjenningstatusen innebærer at vedkommende fort kommer i politiets søkelys. Ikke overraskende skårer forutinntatthet høyest i studentenes Kjenningeksempler - i det «å kjenne noen» ligger jo blant annet nettopp det å kunne forutsi adferd. Overfor personer karakterisert som Kjenning, trekker dessuten studentene relativt ofte inn medfølelse. For eksempel kan det dreie seg om etterforskning av innbrudd hos en person som studenten flere ganger har vært i kontakt med tidligere, men da som aggressiv gjerningsperson. På stedet oppfattes patruljens 
arbeid som mindre grundig enn det ville vært om vedkommende hadde vært et ubeskrevet blad. En student beskriver eksempelvis hvordan det å se en kjenning i fornærmet-rollen gav et innblikk i et «ensomt liv preget av påtatt selvsikkerhet». For studenten leder denne innsikten til en gryende medfølelse og tanker om at politiet burde ha etterforsket grundigere og møtt vedkommende på en mindre forutinntatt måte.

I halvparten av tilfellene beskrives personene karakterisert som Kjenning også som Rusbelastet. I de femten tilfellene av Kjenning/Rusbelastet, domineres verdilandskapet av lovverk og den sjeldnere nevnte verdien orlighet. Sistnevnte opptrer for eksempel i forbindelse med «innganger» (anledning til å undersøke) som studenten tidvis mener blir for kreative. Eller det kan gjelde utsagn betjenter kommer med, som at «det er det beste for deg om du legger alle kortene på bordet», når det snarere er slik at dette bare letter politiets etterforskning.

I 27 av besvarelsene står personer karakterisert som «Psykisk syk» i sentrum for utfordringen. Verdimessig domineres disse møtene av tvangsmakt og verdighet, og slik skiller disse møtene seg fra de foregående konfliktene. Personene det er snakk om da, er ofte Hjelpetrengende og tenkes nok på som «sårbare» i større grad enn andre klienter. Det samme kan også sies om kategorien 'Ung' som omfatter personer under 18 år, og der mange også er under den kriminelle lavalderen. Ung befinner seg i samme verdilandskap som Psykisk syk-kategorien (og det er ca. $50 \%$ overlapp mellom personer som karakteriseres slik). Deres unge alder gjør at bruk av tvangsmakt føles ubehagelig, og verdighet trekkes oftere inn for å beskrive utfordringen enn det mer juridiske lovverk eller formelle likhet. Studentene påpeker i flere tilfeller at «dette kunne ha vært en av mine venner» eller småsøsken.

En klar tendens i materialet er at «mykere» verdier som medfølelse og verdighet trekkes frem i møtene med personer beskrevet som Rusbelastet, Kjenning eller Hjelpetrengende. Når det er en Utenlandsk person som omhandles, er det gjerne de mer formale verdiene likhet og lovverk som fremheves.

\section{Oppdragstyper}

Når det gjelder oppdragstypene, tok kodingen utgangspunkt i politiets oppgaver som beskrevet i Politiloven $₫ 2$, men enkelte oppdragstyper fremsto så brede at det var hensiktsmessig å operere med undergrupper. Ordensoppdrag, f.eks., ble derfor delt opp i ulike typer, ettersom disse var av svært ulik karakter - fra irettesettelse av hundeeiere til hjemkjøring av berusede personer ${ }^{6}$. Ordensoppdrag blir dermed ikke en så fremtredende kategori som det ellers ville vært, men presisjonen i tolkningen blir bedre.

Oftest ble oppdrag som innebar 'Kriminalitetsbekjempelse' nevnt, noe som innebærer at politiet oppsøker steder der konkrete lovbrudd har funnet sted, typisk på oppdrag fra operasjonssentralen. Dette kan dreie seg om butikktyveri eller skadeverk. I 35 av disse 40 oppdragene ble gjerningspersonen beskrevet nærmere. Personbeskrivelsene forteller da at det i 18 tilfeller dreier seg om en 'Rusbelastet' person. Disse begår enten lovbrudd i påvirket tilstand, eller så utgjør bruk/besittelse/salg av rusmidler selve den kriminelle handlingen. I noe mindre grad figurerer her 'Kjenning' (åtte tilfeller), eller 'Utenlandsk' person (sju tilfeller). Verdimessig befinner utfordringene i Kriminalitetsbekjempelse-fortellingene seg i spennet mellom de vanligste verdiene forutinntatthet, lovverk, medfølelse og likhet, og ingen av disse er klart overrepresenterte i disse oppdragene. 
'Trafikkoppdrag' innebærer brudd på Vegtrafikkloven, trafikkulykker og trafikkontroll. I 30 av de 35 trafikkoppdragene lå utfordringen i møtet mellom Politiet og en sjåfør som på en eller annen måte har brutt Vegtrafikkloven. Sjåførene beskrives som Rusbelastet (5), Utenlandsk (4), eller Kollega (3), men i 19 av tilfellene beskrives ikke sjåføren nærmere. ${ }^{7}$ I trafikkoppdrag-seleksjonen dominerer verdien likhet (nevnes i $66 \%$ av tilfellene), etterfulgt av lovverk (26\%). Utfordringen her synes derfor å være hvordan man skal likebehandle «folk flest». Vi har allerede sett eksempel på et slikt scenario ovenfor. At trafikkoppdragene har en så høy frekvens kan forklares ikke bare ved at de aktualiserer skjønnsutøvelse, men også ved at alle studenter - uansett om de er ved små eller store tjenestesteder - utfører denne typen oppdrag og etter hvert med relativt stor grad av selvstendighet.

Ordensoppdrag kategorisert som «stopp og sjekk» (Finstad 2000, Sollund 2007) innebærer kontroll av personer uten at mistanken mot disse personene er konkret. Inkludert i Stopp og sjekk er også «hjemmebesøk», men da som en måte å skaffe inngang til personens bopel. ${ }^{8}$ Stopp og sjekk-oppdragene utgjør 30 av de 208 beskrevne hendelsene og sentralt i disse oppdragene står oftest et møte mellom Politiet og personer beskrevet som Rusbelastet (15) eller Kjenning (9). I tillegg beskrives sju personer som Utenlandsk, hvilket i denne seleksjonen utelukkende vil si menn av østeuropeisk eller afrikansk opphav. Her, som i Kriminalitetsbekjempelse-oppdragene, er Rusbelastet person overrepresentert, og de normene og verdiene studentene oftest trekker frem i de tretti «stopp og sjekk»oppdragene er lovverk og forutinntatthet $(\approx 50 \%)$, deretter arlighet og likhet $(=37$ $\%)$. En nærliggende tolkning av disse funnene er at visse aktører stoppes og sjekkes ut ifra en form for forutinntatthet, og da typisk overfor mennesker som viser rusadferd. Rusbelastede personer behandles dermed ikke på samme måte som folk flest. Et ytterligere moment som oppleves som problematisk er når slike oppdrag endrer karakter. Hvis patruljen for eksempel ikke lykkes med å påvise salg av narkotika, kan vedkommende bli pågrepet for besittelse. Slike skifter er ennå tydeligere når man har hjemmel for å undersøke ett forhold, men oppdager og blir mer fokusert på andre forhold underveis. Dette kan gå på oerligheten løs, særlig hvis kreativiteten i forhold til å avdekke lovbruddet blir stor. Samtidig kan man ikke lukke øynene for det man oppdager underveis. Makkers «tegn og symptomer»vurderinger (Kjeldsen et al, 2011), som studenten ikke forstår eller klarer å verifisere selv, er et eksempel på noe som kan «avspore» et oppdrag.

'Bistandsoppdrag' utgjøres i denne studien av oppdrag der politiet er tilkalt av helsetjenesten eller barnevernet, eller der det blir klart at ordensforstyrrelsen skyldes at personen har en psykiatrisk lidelse. 25 eksamensbesvarelser beskriver slike oppdrag, og de fleste (19) beskriver utfordringer knyttet til person betegnet som Psykisk syk. I fem av tilfellene er disse også karakterisert som Ung. Av verdier nevnes tvangsmakt som utfordrende $\mathrm{i}$ om lag halvparten av tilfellene, dernest verdighet og medfølelse (begge i en tredel av tilfellene). Studentene synes typisk at utfordringen er at tvangsmakt blir brukt for raskt eller i for stor grad. A benytte tvangsmakt overfor syke eller unge er heller ikke hva man i utgangspunktet tenkte på som «politiarbeid». Denne typen ordensoppdrag skiller seg fra andre oppdrag, både ut ifra sitt verdilandskap og gjennom at politiet står overfor personer som er hjelpetrengende. Et typisk eksempel på denne kategorien oppdrag er beskrevet ovenfor, under tvangsmakt. 


\section{Sammenfatning}

Etter å ha kodet eksamensbesvarelsene ut ifra deres perspektiver på verdilandskap, personbeskrivelse og oppdragstype, fant vi at forutinntatthet, Rusbelastet og Kriminalitetsbekjempelse var de hyppigst forekommende kategoriene i hvert sitt perspektiv. Men kombinasjonen av disse tre var ikke spesielt fremtredende. De vanligste «triplene» i materialet er, med frekvens i parentes, følgende:

- Trafikk-Ubeskrevet-likhet (19)

- Bistand-Psykisk syk-tvangsmakt (10)

- Stopp og sjekk-Utenlandsk-forutinntatthet (7)

- Bistand-Psykisk syk-verdighet (7)

- Stopp og sjekk-Rusbelastet-lovverk (7)

- Kriminalitetsbekjempelse-Rusbelastet-lovverk (7)

- Stopp og sjekk-Rusbelastet- orlighet (6)

- Kriminalitetsbekjempelse-Utenlandsk-forutinntatthet (6)

Selv om frekvensene av disse triplene synes små, utgjør de samlet en tredjedel av materialet ${ }^{9}$. Triplene gir et utgangspunkt for å bestemme hvilke utfordringer som er vanlige, men slik vi ser det bør de også understøttes av de vanligste kombinasjonene av Aktør/verdi, ettersom det er menneskemøtene - mer enn oppdragstypene - som er bestemmende for at en moralsk utfordring oppstår. De Aktør/verdikombinasjonene som tydeligst skiller seg ut er forutinntatthet og likhet i møtet med Utenlandsk person, lovverk i møtet med Rusbelastet person, og forutinntatthet og medfølelse i møtet med Kjenning. De triplene som underbygger disse tendensene blir da ytterligere kvalifisert. Ettersom det er ca. 50 \% overlapp i aktørbeskrivelsene Psykisk syk og Ung, og disse kategoriene dessuten har lignende verdilandskap, synes det rimelig å inkludere et scenario der Politiet møter en Psykisk syk - eller Hjelpetrengende - ungdom, og der både tvangsmakt og verdighet står på spill. $\mathrm{Da}$ beskriver følgende tripler de vanligste scenarioene:

I. Trafikk-Ubeskrevet-likhet: Eksempelvis en trafikkontroll der studenten utsteder forenklede forelegg til bilister som oppgir mer eller mindre gode grunner for sin overtredelse av Vegtrafikkloven. Utfordringen består $\mathrm{i}$ å vurdere når en grunn er god nok til å gjøre unntak og når man bør være konsekvent.

II. Bistand-Ung/Psykisk syk-tvangsmakt/verdighet: Studenten ønsker i mange av disse tilfellene at kommunikasjon skal forsøkes i større grad enn hva tilfellet er for makker. De stusser ofte også på nødvendigheten av å benytte tvangsmidler på tilsynelatende rolig ungdom med slike problemer. Dette går som vi har sett typisk på de hjelpetrengendes verdighet løs.

III. Kriminalitetsbekjempelse-Rusbelastet-lovverk/oerlighet: Her rykker f.eks. patruljen ut til et lovbrudd begått av personer med rushistorikk. Ved ransaking av disse, finner patruljen brukerdoser som blir hovedfokus i det videre. Studentene mener at funnet bør få konsekvenser, men er usikker på om ikke dette bare skaper ytterligere kriminalitet. Hvis studenten mener at patruljen har skaffet seg adgang til ransaking på spinkelt grunnlag, forsterkes utfordringen.

IV. Kriminalitetsbekjempelse-Kjenning-forutinntatthet/medfølelse. En Kjenning har blitt utsatt for en forbrytelse, og selv om vedkommende får korrekt behandling, overanstrenger ikke patruljen seg i sakens anledning. Studenten ser poenget, men ser også den menneskelige siden ved Kjenningen og opplever medfølelse med vedkommende. 
V. Stopp og sjekk-Utenlandsk-forutinntatthet. Disse tilfellene innebærer gjerne «Stopp og sjekk» av øst-europeiske eller afrikanske menn som makker mener har begått kriminalitet, uten at studenten ser at det egentlig er annet enn utseende som ligger til grunn for sjekken. Ofte trekkes tid og sted inn i diskusjonen av hvorfor disse blir sjekket, men studentene finner ikke nødvendigvis noe mistenkelig ved disse.

Disse fem scenarioene ivaretar de vanligste oppdragene, aktørene og verdiene; de ivaretar de overrepresenterte Aktør/verdi-kombinasjonene, og de vanligste triplene. I tillegg beskrives den vanligste verdikombinasjonen (forutinntatthet/medfølelse). Dermed mener vi forskningsmaterialet ivaretas av disse scenarioene.

Scenarioene representerer en begynnende teoretisering av forskningsmaterialet, og danner 'hypoteser' om hva som er de vanligste utfordringene for studentene. For at funnene skal inngå i kunnskapsutviklingen, kan og bør disse hypotesene testes i undervisningen og gjennom intervjuer av veiledere og studenter ute i praksis - for bare unntaksvis skriver studentene at de har lagt sin tvil åpent frem for veileder/makker i etterkant. I noen få tilfeller skriver faktisk studentene at de fikk beskjed av overordnet om ikke å nevne tjenestehandlingene i refleksjonsnotatene sine. Eksemplene som fremkommer i denne studien gir imidlertid en kontekst til også å ta opp nettopp slike spørsmål.

Alle de fem scenarioene kan tolkes som studentenes mangel på situasjonsforståelse og uferdige dømmekraft - kort sagt at studentene ikke har maktet å adoptere politirollen fullt ut. Kanskje har studentene dels en for prinsippryttersk holdning - de må følge boka - og dels er de for ettergivende i kontakt med personer fra miljøer der det å lure politiet nærmest er en dyd. Handlingsrepertoaret deres er for lite, og de klarer ikke å skjelne nyansene i situasjonene (Finstad 2000: 89). Men samtidig kan det hevdes at scenarioene (se IIIV) underbygger negative karakteristikker av politikulturen som ofte fremholdes i politivitenskap, som for eksempel jaktlyst, kynisme, generell mistenksomhet, fordomsfullhet overfor visse grupper, samt pragmatisme (Reiner 2000: $87 \mathrm{ff}$, Hellesø-Knutsen 2013). Men det kan også argumenteres for at disse karakteristikkene ikke er ubetinget negative. Jaktlysten uttrykker engasjement - det å være «tett på» som det heter i Politidirektoratets medarbeiderplattform; det som virker kynisk og kanskje fordomsfullt for en utenforstående er realisme basert på bred erfaringskunnskap, og pragmatismen er en form for jordnærhet snarere enn en krass, anti-intellektuell holdning. Studentene synes i eksamensbesvarelsene gjennomgående å forholde seg ambivalent til slike politikulturelle trekk, snarere enn å være fordømmende overfor sine overordnede. Det som er et praksissjokk har dessuten ofte også karakter av et praksis-«kick» (Eriksen \& Huemer 2013). Studentene beskriver anekdotisk møtet med politirollen i andreåret som preget av spenning, nysgjerrighet, usikkerhet og etter hvert også mestringsfølelse.

Skjønnsutøvelse i form av en vurdering av mennesker står helt sentralt i scenario III-V, ikke bare ut ifra utseende (etnisitet, kjønn, bilskilt), men også ut ifra avvikende oppførsel (tid og sted), og ut ifra kjennskap («han er en kjent for oss»). Dette helt i tråd med Holmbergs litteraturgjennomgang og observasjoner (Holmberg 1999). Skjønnsutøvelse kreves også i scenario I og II. I scenario I, er det fokus på å identifisere grunner som er gode nok for å forskjellsbehandle - såkalt «moralsk relevante forskjeller» (Kvalnes 2008). Dette er vanskelig i praksis, ettersom 
grunnene bør være gode nok fra et slags upartisk ståsted og ikke bare uttrykk for betjentens/studentens smak og behag. Selv i trafikkontroller (Scenario I), som er en relativt forutsigbar arbeidsoppgave, viser dette seg utfordrende. Privilegiet å kunne benytte konduite (se gjennom fingrene med noe), er bare legitimt hvis man har en form for spesialkunnskap som profesjonsutøver (Kleinig 1996a: 83) - og selv om man aksepterer at politiyrket er en profesjon, vil man neppe si at en politistudent under utdanning besitter spesialkunnskap, selv om hun eller han har politimyndighet. Dessuten er skjønnsutøvelse - som Kleinig har vist annetsteds - et mangfoldig begrep, der skjønn ikke bare benyttes for å identifisere moralsk relevante forskjeller, men også i forhold til hva som bør være politioppgaver (scope, omfang), prioritering av oppgaver, samt taktikk (Kleinig 1996, s. 4 ff.). Både omfang og taktikk-komponentene er tydelige i scenario II, der utfordringen beskrives som bruk av makt overfor hjelpetrengende. Er dette en politioppgave, og hvordan skal man bistå polisiært uten unødig å krenke en som er hjelpetrengende? Uten erfaring er dette et vanskelig spørsmål å besvare. Politimyndigheten gir relativt stor adgang til skjønnsutøvelse i Norge, og selv om studentene mener at mer erfarne politibetjenter kommuniserer for lite eller bruker for mye makt, er det ikke dermed sagt at deres alternative tanker om oppdragsløsning nødvendigvis er hensiktsmessige.

Så hvordan kan studentene komme bedre forberedt til praksisåret? Om de hadde reflektert godt over scenariene som trekkes frem her, kunne det i noen grad virke som en mental forberedelse på praksisåret. Det å lære om noe på skolebenken oppleves imidlertid forskjellig fra faktisk å stå i situasjonen. Praktiske øvelser på forhånd kunne gjøre problemstillingene mer realistiske, men tilfellene kan variere så mye at generalisering ut ifra ett eksempel kan være vanskelig. Øvelse i det å se overføringsverdien (likheter/forskjeller) fra sak til sak vil derfor være nødvendig altså opplæring i en form for kasuistikk (Jonsen \& Toulmin 1988).

Likevel er det nok illusorisk å tro at «teori» og praksis her skal kunne koherere (Smeby \& Heggen 2014). Et vesentlig poeng i den sammenhengen er jo dessuten at studentene, i de aller fleste tilfellene, beskriver situasjoner der det ikke er dem selv som bidrar til at situasjonen blir utfordrende. Hovedutfordringen blir da snarere å finne ut hvordan man kan få en konstruktiv dialog rundt slike situasjoner, og det krever at man setter av tid til nettopp dette. Studentene vet jo at deres egnethet også vurderes ut ifra lojalitet og modenhet. Dermed er det lite fristende å fremstå som kritisk og usikker. Det er derfor avgjørende at man skaper en «trygg» situasjon for å få i gang en god prosess. Studenter og veiledere må ha et felles begrepsapparat og hensiktsmessige måter å diskutere utfordringer på. Forberedelsen må derfor, etter det perspektivet som anlegges her, innebære rutiner for kritisk å vurdere oppdragsløsninger, dvs. debriefinger som tar hensyn til ikke bare de tekniske og taktiske sider ved oppdragene, men også de skjønnsmessige og moralske sidene. Politihøgskolen, veiledere og etaten generelt har her et ansvar for å ta vare på studentenes tause skepsis.

\section{Noter}

${ }^{1}$ Forfatterne har bakgrunn fra undervisning og administrasjon av politistudenter. Materialet ble først kodet separat av første- og andreforfatter. Politioverbetjent Rolf- 
Eric Birkenes var behjelpelig med sikring av terminologien og case i en tidlig fase av prosjektet.

${ }^{2}$ Hvor viktig «sannheten» er i en sammenheng som denne kan også diskuteres. Forvrengninger og tilpasninger kan være av verdi i forskningssammenheng (Sandberg 2010), og slike er kanskje spesielt viktig å ivareta $i$ en utdanningssammenheng.

${ }^{3}$ Vi tolket verdilandskapet bredt og i tråd med Svein Aage Christoffersens ulike kilder for profesjonell dømmekraft, som er pensum for studentene (Christoffersen 2011: 72).

${ }^{4}$ På samme måte som helsepersonell har et «klinisk blikk» (Ellefsen, Kim, \& Han 2007).

${ }^{5}$ Når rollen ses i sammenheng med personbeskrivelse, peker særlig tre møter seg ut, nemlig 1) politiets møte med Rusbelastet Gjerningsperson; 2) møtet med Hjelpetrengende Psykisk syk person; og til sist 3) når det gjelder møtet med publikum og møtet med «Tilstedeværende» Utenlandsk person.

6 Jfr. Bittners generelle formulering om omfanget av politiets potensielle arbeidsoppgaver: "Something-that-ought-not-to-be-happening-and-about-whichsomeone-had-better-do-something-now!" (Bittner 2005: 161)

${ }^{7}$ Verdt å merke seg, er også at det i materialet kun fire ganger oppstår utfordringer knyttet til gjerningsperson betegnet som 'politibetjent'. Tre av disse finnes i trafikkoppdrag.

${ }^{8}$ Denne oppdragstypen er beslektet med Kriminalitetsbekjempelse - men uten at politiet responderer på et konkret lovbrudd / har konkrete mistenkte, og med Trafikk - men uten at man da har Vegtrafikklovens fullmakter.

${ }^{9}$ De kategoriene som diskuteres ovenfor muliggjør 120 tripler. «Sannsynlige» tripler som Kriminalitetsbekjempelse-Utenlandsk-medfølelse og TrafikkoppdragKjenning-forutinntatthet finnes f.eks. ikke i materialet.

\section{Litteratur}

Abbott, H. P. (2002). The Cambridge Introduction to Narrative. Cambridge: Cambridge University Press.

Beauchamp, T. L., \& Childress, J. F. (2009). Principles of Biomedical Ethics (6 ed.). New York \& London: Oxford University Press.

Bittner, E. (2005). Florence Nightingale in pursuit of Willie Sutton: a theory of the police. In T. Newburn (ed.), Policing: key readings. Devon: Willan Publishing.

Christoffersen, S. A. (2011). Profesjonsetikk. Om etiske perspektiver i arbeidet med mennesker (2. utg). Oslo: Universitetsforlaget.

Diderichsen, A. (2011). Etik for politifolk. Fredriksberg: Samfundslitteratur.

Ellefsen, B., Kim, H. S., \& Han, K. J. (2007). Nursing gaze as framework for nursing practice: a study from acute care setting in Korea, Norway and the USA. Scandinavian Journal of Caring Sciences, 21, 98-105. https://doi.org/10.1111/j.1471-6712.2007.00439.x

Epstein, E. G., \& Delgado, Sarah. (2010). Understanding and Addressing Moral Distress. Online Journal of Issues in Nursing. 15 (3). Lastet ned 22.09.2016. https://doi.org/10.3912/OJIN.Vol15No03Man01 
Eriksen, L. og Huemer, J. (2013). Dialogkonferanse i klasserommet - bro til bedre læring. Norsk pedagogisk tidsskrift 1 (Volume 97)

Finstad, L. (2000). Politiblikket. Oslo: Pax Forlag A/S.

Freidson, E. (2007). Professionalism the third logic. Cambridge, UK Malden, MA: Polity Press.

Glaser, B. G., \& Strauss, A. L. (1999). The Discovery of Grounded Theory: Strategies for Qualitative Research. New Brunswick \& London: Aldine Transaction.

Gundhus, H. I. (2009). For sikkerhets skyld : IKT, yrkeskulturer og kunnskapsarbeid i politiet. Oslo: Unipub.

Granér, R. (2004). Patrullerande polisers yrkeskultur. Lund: Lund Dissertations in Social Work 18.

Hare, R. M. (1952). The language of morals. Oxford: Oxford University Press.

Hellesø-Knudsen, K. (2013). Jakten på risiko: vurderinger, følelser og valg hos patruljerende politi. Stavanger: University of Stavanger, Faculty of Social Sciences.

Holmberg, L. (1999). Politiets skøn i retssociologisk belysning. Ph.d-avhandling. København: Københavns Universitet.

Johannessen, S.O. (2013). Politikultur : identitet, makt og forandring i politiet. Trondheim: Akademika.

Jonsen, A. R. og S. Toulmin (1988). The Abuse of Casuistry: A History of Moral Reasoning Berkeley: University of California Press.

Kleinig, J. (1996). Handled with discretion. Ethical issues in police decision making. Lanham: Bowman \& Littlefield Publishers.

Kleinig, J. (1996a). The ethics of policing. Cambridge: Cambridge University Press. https://doi.org/10.1017/CBO9781139172851

Kjeldsen, T., Sundvoll, A., \& Øiseth, O. V. (2011). Tegn og symptomer (3. utg.). Oslo: Vett \& Viten.

Kvalnes, Ø. (2008). Se Gorillaen! Etikk i arbeid. Oslo: Universitetsforlaget.

MacVean, A., og Neyroud, P. (2012). Police ethics and values. London: Sage.

Morse, J. M., Barrett, M., Mayan, M., Olson, K., \& Spiers, J. (2002). Verification Strategies for Establishing Reliability and Validity in Qualitative Research. International Journal of Qualitative Methods, 1(2), 13-22. https://doi.org/10.1177/160940690200100202

Nanda, A. (2003). The Essence of Professionalism: Managing Conflicts of Interest. Harvard Business Review, Industry and background note.

NOU 2012:14. Rapport fra 22. juli-kommisjonen. Oslo: Departementenes servicesenter.

NOU 2013: 9. Ett politi - rustet til å møte fremtidens utfordringer (Politianalysen). Oslo: Departementenes servicesenter.Olsen, L. N. (1995). Politilære og yrkesetikk. Oslo: Politihøgskolen.

Politiinstruksen (1990). http://lovdata.no/dokument/INS/forskrift/1990-06-223963. Innhentet 27.02.14.

Politiloven (1995). http://lovdata.no/dokument/NL/lov/1995-08-04-53. Innhentet 27.02.14.

Reiner, R. (2000). The politics of the police. (3. Utgave). Oxford: Oxford University Press. 
Sandberg, S. (2010). What can "Lies" Tell Us about Life? Notes towards a Framework of Narrative Criminology. Journal of Criminal Justice Education, 21(4), 447-465. https://doi.org/10.1080/10511253.2010.516564

Sjøtrø, A., \& Olsen, P. I. (2013). Magefølelse som kunnskapsform. En innsatsleders tilnærming til krevende oppdrag. (Master), Handelshøjskolen i København, København. Lastet ned fra http://hdl.handle.net/11250/147282

Smeby, J.-C. (2007) Connecting to professional knowledge. Studies in Higher Education. Volume 32 (2). https://doi.org/10.1080/03075070701267251

Smeby, J.-C., Heggen, K. (2014) Coherence and the development of professional knowledge and skills. Journal of Education and Work. Volume 27(1). https://doi.org/10.1080/13639080.2012.718749

Sollund, R. A. (2007). Tatt for en annen. En feltstudie av relasjonen mellom etniske minoriteter og politiet. Oslo: Gyldendal.

Tjora, A. (2012). Kvalitative forskningsmetoder i praksis (2. utgave ed.). Oslo: Gyldendal Akademisk.

Wittgenstein, L. (1997). Filosofiske undersøkelser. Oslo: Pax Forlag A/S.

Winnæss, P., \& Helland, H. (2014). Politistudentene: Hvem er de og hvorfor vil de bli politi? Nordisk politiforskning(2), 94-123. 